\title{
RITUAL DALAM SIKLUS HIDUP MASYARAKAT BAJO DI TOROSIAJE
}

\section{RITUALS ON THE BAJO LIFE CYCLE IN TOROSIAJE}

\author{
Kamaruddin Mustamin \\ Fakultas Ushuluddin dan Dakwah IAIN Sultan Amai Gorontalo \\ Jl. Sultan Amay, Pone, Limboto Bar., Kota Gorontalo \\ Email: kamaruddinmustamin@gmail.com \\ Sunandar Macpal \\ IAIN Sultan Amai Gorontalo \\ J1. Sultan Amay, Pone, Limboto Bar., Kota Gorontalo \\ Email: sunandarmacpal@gmail.com
}

Naskah diterima tanggal 12 April 2020, Naskah direvisi tanggal 21 Mei 2020, Naskah disetujui tanggal 9 Juni 2020

\begin{abstract}
Abstrak
Penelitian ini bertujuan untuk melihat sistem siklus hidup dan perubahannya dalam masyarakat Bajo di Torosiaje. Penelitian dilakukan di tiga desa yang termasuk dalam Bajo Serumpun yakni Desa Torosiaje, Torosiaje Jaya dan Bumi Bahari. Pengumpulan data menggunakan observasi, wawancara dan FGD. Temuan penelitian menunjukkan bahwa dalam melewati setiap siklus hidup pada masyarakat Bajo selalu dilakasaakan ritual/maupun tradisi adat. Pada fase kehamilan atau Bitta sudah dilaksanakan ritual pemasangan sangkine begitu juga pada fase ngana/ana' dilaksanan ritual berupa ngita ura (pemotongan tali pusar bayi), temuni, tiba kaka dan bantang. Pada fase bayi dilaksaakan ritual kukkor (gunting rambut) dan sunna (sunat bagi anak perempuan). Pada fase remaja dilaksanakan sunna, (sunnat bagi laki-laki) dan baiat bagi anak perempuan. Pada fase dewasa dan menikah dilaksanakan prosesi massuroh dan nabo botte. Sementara pada fase kematian/kapatayang dilaksanakan ritual melaku tana untuk penggalian kubur, dan ngalabangi untuk pelaksanaan doa tahlilan. Pemindahan suku bajo kemudian melahirkan segregasi pada masyarakat Bajo sehingga melahirkan istilah Bajo Darat dan Bajo Laut. Bagi Bajo Darat, bajo laut merupakan culture core atau pusat kebudayaan orang Bajo sehingga segala bentuk kebudayaan selalu merujuk pada Bajo Laut. Hal paling mendasar dalam perubahan dalam siklus hidup dari masyrakat Bajo adalah soal nilai dari sebuah ritual. Ritual pada masyarakat Bajo Darat tetap dilaksanakan, namun pada beberapa aspek seakan telah kehilangan esensi dari ritual tersebut. Perubahan yang terjadi selain karena faktor ekologi, ternyata kehadiran negara menjadi faktor yang turut mempengaruhi perubahan sosial masyarakat Bajo di Darat
\end{abstract}

Kata Kunci: bajo, torosiaje, siklus hidup, perubahan

\begin{abstract}
This study aims to look at the life cycle system and its changes in the Bajo community in Torosiaje. The study was conducted in three villages included in Bajo Serumpun namely Torosiaje, Torosiaje Jaya and Bumi Bahari villages. Data collection uses observation, interviews and FGD. The research findings show that in passing through every life cycle in the Bajo community, rituals and traditional traditions are always carried out. During the pregnancy or Bitta phase, a sangkine installation ritual is carried out as well as the ngana / ana phase where the rituals take place in the form of ngita ura (cutting of the baby's umbilical cord), meet, arrive kaka and bantang. In the baby phase the rituals are performed kukkor (hair clippers) and sunna (circumcision for girls). In the adolescent phase, there is sunna, (circumcision for boys) and baiat for girls. In the adult and married phases a massuroh and nabo botte procession is carried out. While in the phase of death / kapatayang carried out rituals of tana for the excavation of the grave, and ngalabangi for the implementation of prayer tahlilan. The removal of the Bajo tribe then gave birth to segregation in the Bajo community so that it gave birth to the terms Bajo Darat and Bajo Laut. For Bajo Darat, Bajo laut is a culture core or Bajo culture center so that all forms of culture always refer to Bajo Laut. The most fundamental thing in the changes in the life cycle of the Bajo people is a matter of the value of a ritual. Rituals in the Bajo
\end{abstract}


Darat community continue to be carried out, but in some aspects it seems to have lost the essence of the ritual. Changes that occur other than due to ecological factors, it turns out that the presence of the state is a factor that also influences the social changes in the Bajo Darat community.

Keywords: bajo, torosiaje, life circle, changes

\section{PENDAHULUAN}

$\mathrm{B}$ ajo merupakan salah satu suku bangsa yang menggantungkan hidupnya di laut dan tersebar tidak hanya di wilayah Indonesia tapi juga di Australia, Malaysia, dan Filipina (Lihat, Lebar,1975; Sembiring, 1993, Spillet, 1993; Zada Ua, 1996). Di Indonesia suku Bajo tersebar di sekitar pantai timur Sumatera, yang hidup berpindah-pindah di pinggir pantai sekitar pantai Riau hingga ke Tanjung Jabung dekat Jambi ke Kabupaten Indragiri Hilir. Oleh masyarakat mereka sering disebut "orang laut" (Sembiring, 1993). Selain suku ini dapat dijumpai di muara pantai dan daerah lepas pantai utara dan Timur Kalimantan, Kepulauan Maluku, pantai utara Sumbawa, pantai barat dan utara Flores, Pulau Babi, Kepulauan Alor. Di Pulau Sulawesi, Suku Bajo tersebar pada beberapa kabupaten di Sulawesi Selatan, Tengah, Utara, Tenggara dan Gorontalo (Lebar, 1975, Spillet, Zada Ua, 1996, Zacot, 2008, Suyuti 2011).

Persebaran etnis Bajo di Propinsi Gorontalo sendiri tersebar di pesisir pantai teluk Tomini yakni di Kabupaten Boalemo dan di Kabupaten Pohuwato. Suku Bajo di Torosiaje seperti kebanyakan Suku Bajo lainnya awalnya hanya merupakan kumpulan soppe-soppe (perahu besar tempat orang bajo tinggal). Tahun 1901, Torosiaje hanya merupaknan tempat singgah yang singkat bagi Orang Bajo.

Mereka berpindah-pindah tempat di teluk Tomini dalam, kelompok lima sampai sepuluh sopped an singgah di pantai pulaupulau di sana. Pada saat itu seorang Haji hidup di pulau tempat sekarang terdapat desa Torosiaje. Awalnya orang Bajo hanya singgah untuk menjual ikan dan kulit penyu. Mereka menyebut tempat itu sebagai Toro (tanjung) si haji. Tahun 1926, Torosiaje kemudian dijadikan sebagai perkampungan walaupun saat itu orang Bajo masih tinggal di atas perahu (Zacot, 2008: 73-74)
Masyarakat Bajo di Torosiaje kemudian mulai membangun rumah di atas laut dengan menggunakan tiang kayu. Sekitar tahun 1980-an pemerintah pusat melaui program yang dilaksanakan oleh Kementerian Sosial kemudian berusaha memindahkan Orang Bajo ke darat. Pemindahan suku Bajo dari laut ke darat di Torosieja merupakan inisiasi dari pemerintah pusat. Awalnya ada sekitar $125 \mathrm{KK}$ yang dipindahkan ke darat (saat ini sudah menjadi Desa Bumi Bahari). Dari 125 KK tersebut, sebagian besar kemudian memilih untuk kembali ke laut dengan alasan ketersediaan air bersih dan jarak yang jauh dari laut. Hanya tersisa sekitar $35 \mathrm{KK}$ yang masih bertahan di daratan (Wawancara Umar Pasande).

Pemindahan masyarakat melalui Sistem Pemukiman Sosial (SPS) disertai dengan jaminan hidup selama tiga tahun. Walaupun sudah deberikan jaminan hidup dan lahan pertanian, banyak Orang Bajo yang tetap memilih kembali ke laut. Awal tahun 1990, pemerintah kembali melakukan intervensi untuk memindahkan orang Bajo ke darat. Pada proses yang ke dua ini banyak yang kemudian menetap di darat namun tetap memilih lokasi dekat dengan pantai.

Seiring berjalannya waktu, keterbatasan lokasi untuk membangun rumah di atas laut, mengakibatkan orang Bajo mulai melakan migrasi ke darat. Selain keterbatasan lahan, mulai langka-nya kayu sebagai bahan pembuat rumah menjadi alasan mereka untuk tinggal di darat. Saat ini, Torosiaje Serumpun sudah dimekarkan menjadi tiga desa yakni Desa Torosije (perkampungan di atas laut), Torosiaje Jaya (diwilayah pesisir) dan Bumi Bahari, berjarak kurang lebih 2 KM dari pesisir dan lebih dekat dengan pasar. Walaupun sudah dipisahkan secara administrasi, penduduk dari tiga desa mengidentifikasikan diri mereka sebagai orang Bajo Torosiaje Serumpun. Secara 
ekologi, masyarakat Bajo yang dahulunya tinggal di atas laut, saat ini sudah terpisah.

Keberadaan masyarakat Bajo di Torosiaje Serumpun yang terpisah secara ekologi tentu akan memberikan dampak pada aspek kehidupan baik itu secara sosial maupun kebudayaan. Space, dan ekologi yang berbeda antara Bajo Laut dan Darat tentu saja berdampak pada adanya perubahan yang terjadi pada masyarakat. Perbedaan space, ekologi yang berbeda ini membuat penelitian terhadap perubahan sosial yang terjadi pada masyarakat Bajo di Torosiaje Serumpun menjadi penting. Life circle masyarakat Torosiaje Laut yang dianggap oleh masyarakat sebagai culture core orang Bajo di Torosiaje Serumpun akan dibandingkan dengan life circle masyarakat di Torosije Darat. Selajutnya penelitian dipusatkan pada: (1)Bagaimana ritual dalam siklus hidup masyarakat Bajo di Torosiaje Serumpun baik di laut maupun di darat?, dan (2) Bagaimana perubahan ritual dalam siklus hidup pada masyarakat Bajo di darat?

\section{TINJAUAN PUSTAKA}

Pemindahan suku Bajo yang awalnya berada di atas laut kemudian dipindahkan ke darat, tentu akan melahirkan pola adaptasi dari masyarakat itu sendiri. Pemahaman terhadap dimensi ekologis suatu kebudayaan, membutuhkan perspektif yang meletakan kebudayaan sebagai bagian dari usaha manusia untuk beradaptasi dengan lingkungan. Dalam perspektif seprti ini, manusia menjadi bagian dari sebuah jaringan ekosistem. Keterkaitan manusia dengan lingkungan sekitarnya dalam suatu jaringan yang saling berhubungan merupakan hal penting dalma usaha manusia untuk mempertahankan hidupnya (Hawley, 1986: 328-337).

J. W Bennet mengemukakan bahwa adapatasi merupakan alat untuk mencapai tujuan. Adapatsi selanjutnya dapat dikategorikan pada tahapan individu dan komunitas. Pada tahapan individu, manusia selalu berusaha menyesuaikan diri dengan situasi lingkungan, agar dapat memperoleh apa yang diinginkan. Pandangan ini menakankan bahwa antara individu akan memiliki pola adaptasi yang berbeda. Adaptasi bukan hanya sekedar kemampuan untuk menyesuaikan diri pada kondisi lingkungan, namun juga mengandung arti memiliki suatu kemampuan berfungsi dengan baik dalam lingkungan yang berbeda. Dalam proses adaptasi, individu yang terlibat menggunakan pengetahuan yang dimilikinya mengenai lingkungan, baik fisik maupun sosial budaya. Pengetahuan ini diperoleh dari hasil interaksi dari masing-masing individu dan dengan lingkungan maupun orang lain (Bennet, 1996; lihat juga Muslim, dkk: 2019) Selain pola adaptasi terhadap lingkungan, perubahan sosial dalam sistem kebudayaan orang Bajo di Torosiaje juga terjadi. Perubahan sosial budaya yang dialami setiap komunitas mayarakat terjadi akibat adanya reaksi setiap orang dalam merespon berbagai interaksi dengan lingkungannya baik lingkungan fisik maupun lingkungan sosial. Setiap respon yang diberikan akan melahirkan kosekuensi dalam kehidupan selanjutnya baik secara positif maupun negatif (Spradley, 1997: 120-122). Konsep perubahan sosial menurut Geertz (1973) dapat terjadi karena adanya faktor dalam diri kebudayaan itu sendiri di mana para penganutnya merasa bahwa beberapa prantan kebudayaan harus diubah dan disesuaikan dengan perkembangan obyektif di dalam kehidupan sosialnya (Geertz, 1973).

Etnis Bajo di Torosiaje sudah sejak lama menjadi lokus penelitian baik peneliti dari Indonesia mapun luar negeri. Usman (2013) dalam makalahnya yang disampaikan pada kongres kebudayaan Indonesia di Yogyakarta menemukan bahwa sistem sosio kultur-ekologi dan sistem pengelolaan tradisional, masih merupakan komponen kunci identitas mereka yang memiliki sifatsifat yang dapat mempromosi kestabilan dan dapat merespon perubahan-perubahan. Namun eksploitasi lingkungan alam praktik, pemanfaatan sumber-sumber yang tidak berkelanjutan menjadi ancaman nyata pada sistem subsistensi.

Utina (2012) dalam penelitiannya terkait kecerdasan ekologi orang Bajo di Torosiaje menemukan bahwa kecerdasan ekologi orang Bajo tampak dalam tradisi melaut mamia kadialo, pengelolaan pemukiman, perilaku dalam memperoleh hasil tangkapan dan pengetahuan masyrakat tetang gejala alam laut dan pesisir. Terkait dengan 
mamia kadiolo, (Baruadi, dkk 2017) juga mengatakan hal yang sama bahwa dalam aktivitas penangkapan ikan, masyarakat Bajo di Torsiaje merujuk pada pengetahuan lokal mereka terkait dengan hirarki dan pembagian kerja saat memancing yang disebut dengan mamia kadiolo.

Hamidun (2016) melakukan penelitian di Torosiaje terkait dengan pengelolaan mangrove. Menurutnya kawasan mangrove di pesisir Torosiaje memiliki potensi untuk pengembangan ekowisata yang ditunjukkan oleh adanya potesnis biologi dengan keragaman jenis tumbuhan mangrove, jenis fauna dan ekosistem terumbu karang, serta kearifan lokal suku bao dan perkampungan suku Bajo yang terletak di atas perairan.

Umar (2018) dalam penelitiannya menemukan bahwa masyarakat suku Bajo yang berada pada pemukiman terapung memiliki kearifan lokal berupa hukum adat bersumber pada keyakina, berkembang melalui proses adaptasi yang telah diwariskan dari generasi ke generasi. Kearifan lokal ini diyakini dapat menciptakan keselarasan, keserasian, keseimbangan dan kelestarian antara manusia dan lingkungan alam di pemukiman terapung serta tanggap terhadap perubahan iklim. Di mana pola adaptasi terhadap perubahan iklim merupakan pola adaptasi budaya dan pola adaptasi tangkah laku.

Obie dkk (2014) membuat penelitian terkait dengan konflik yang terjadi pada masyakat Bajo di Torosiaje. Dalam penelitian tersebut, Obie, dkk (2014) menemukan bahwa konflik etnis yang terjadi di pesisir teluk tomini disebabkan oleh kebijakan pemerintah yang memberikan izin pengelolaan wilayah pesisir kepada perusahaan kayu dan usaha tambak. Kebijakan tersebut berbenturan dengan kepentingan suku bajo yang sudah puluhan tahun membangun sistem sosial dan ekonomi di pesisir Teluk Tomini.

Konflik yang terjadi berupa konflik otoritas, pengetahuan dan nafkah. Resolusi konflik melauli dialog talah dilakukan tetapi belum sepenuhnya mencapai kesepakatan. Untuk menghindari konflik etnis yang terus berulang, serta memberi kepastian dan perlindungan hukum dalam pemanfaatan wilayah pesisir, maka pemetaan zona menjadi dalan tengah dalam pengelolaan wilayah pesisir.

Beberapa penelitian di atas mengambil seting lokasi yang sama yakni di desa Torosiaje, namun secara metodologi, penelitian sebelumnya belum ada yang melakukan studi komparasi terhadap life circle antara Orang Bajo di laut dan di darat. Hasil penelitian yang paling dekat adalah penelitian yang dilakukan seorang anropolog Prancisn Zacot (2008) yang menulis tentang suku Bajo di Torosiaje. Namun penelitian dan tulisan hasil penelitian tersebut telah diterbitkan kurang lebih sepuluh tahun yang lalu. Dalam rentang waktu 10 tahun tersebut, pasti ada perubahan yang terjadi. Oleh karena itu, penelitian ini hadir untuk mengisi kekosongan tersebut. Baik secara metode yakni komparatif sinkrorik maupun kebaruana atas kebudayaan utamanya life circle orang Bajo di Torosiaje

\section{METODE PENELITIAN}

Penelitian ini dilaksanakan di Kabupaten Pohuwato khusunya pada kantong-kantong Suku Bajo serumpun yang tersebar pada tiga desa yakni Torosiaje, Bumi Bahari dan Torosiaje Jaya Pemilihan lokasi ini dikarenakan tiga desa tersebut merupakan kantong-kantong etnis Bajo yang menurut geanologi berasal dari etnis Bajo di Torosiaje Laut. Hal pertama yang harus dilakukan oleh peneliti lapangan tentu saja adalah bagaimana peneliti diterima oleh masyarakat sehingga mempermudah dalam proses interaksi dan pengumpulan data saat penelitian. Selama proses pengumpulan data, peneliti tinggal di rumah Endi Tendong, yang merupakan Orang Bajo dan tinggal di Torosiaje Laut. Keluarga Endi Tendong, menjadi penghubung peneliti dengan masyarakat. Pengumpulan data lapangan dilaksanakan pada dua tahap, di mana tahap pertama dilaksanakan pada bulan Maret 2018 dan tahap kedua dilaksanakan pada bulan April 2019. Pengumpulan data dilakukan dengan observasi kemudian diperdalam dengan wawancara mendalam bersama dengan partisipan (informan kunci). Mengacu pada Shaugnessy, dkk., (2006) 
tujuan utama dari observasi adalah untuk mendeskripsikan perilaku selengkap dan seakurat mungkin (Shagunessy, dkk., 2006: 109). Dalam proses observasi dan wawancara mengacu pada Achenbach (1978) dengan menggunakan naturalistic setting, dimana proses tersebut disesuaikan dengan kondisi fisik, psikis maupun lingkungan partisipan. Focus Group Discussion juga dilaksanakan dalam pengumpulan data. Tentu saja tanpa melupakan untuk mengumpulkan data sekunder berupa arsip, peta, pustaka maupun jurnal yang relevan dengan topik penelitian ini. Dalam proses wawancara, diberikan pertanyaan umum atau terbuka yang diarahkan pada usaha untuk mengumpulkan data yang akan mengantar pada deskripsi tekstual dan struktural tentang pengalaman dan dapat memberikan yang lebih baik tentang pengalaman yang sama dari para partisipan (Creswell, 2013: 113)

Mengacu pada Moustakas (1994) proses analisis data menggunakan cara horizonalisasi yaitu menyoroti berbagai pernyataaan penting tentang bagaimana para partisipan mengalami suatu fenomena. Pernyataan penting ini kemudian ditulis dalam bentuk deskripsi (deskripsi tekstual), pernyataan penting ini juga digunakan untuk menulis deskripsi tetang konteks atau latar yang memengaruhi bagi partisipan mengalami fenomena tersebut (deskripsi imajinatif/struktural). Deskripsi tekstual dan struktural kemudian digabungkan dan harus mempresentasikan esensi dari fenomena atau yang disebut sebagai struktur invariant esensial yang terfokus pada pengalaman yang sama dari para partisipan

Proses pengumpulan data di lapangan dilaksanakan pada tiga lokasi penelitian. Lokasi pertama adalah Desa Torosiaje (Torosiaje Laut). Torosiaje Laut merupakan tempat yang dianggap oleh Orang Bajo sebagai culture core dari masyarakat Bajo Serumpun di Torosiaje. Di Desa Torosiaje, peneliti berusaha untuk mengumpulkan data terkait life circle (kelahiran, pernikahan dan kematian). Temuan data dari Torosije Laut ini kemudian menjadi acuan dasar untuk melakukan studi komparatif terkait life circle masyarakat Bajo Serumpun yang sudah tinggal di darat.

\section{PEMBAHASAN Bitta' (Fase Kehamilan)}

Kehamilan bagi masyarakat Bajo di Torosiaje disebut dengan Bitta' (dengan penekanan diakhir huruf "a"). Bagi masyarakat Bajo, terdapat beberapa pantangan maupun aturan sosial yang berlaku bagi seorang ibu hamil. Masyarakat Bajo-Laut mempunyai pantangan bagi ibu hamil yaitu pertama; ketika terjadi hujan, petir maupun badai, maka tidak boleh keluar dari rumah karena badai membawa serta penyakit, maupun makhluk gaib yang akan mengganggu janin. kedua; tidak melewati tali di at as kepala maupun melangkahi tali di bawah kaki, hal ini akan mengakibatkan tali pusar dari janin melilit bagian kepala maupun bagian kaki yang akan berdampak meninggalnya janin dalam rahim. Ketiga; tidak boleh duduk di depan pintu. Pantangan ini berlaku supaya bayi tidak tertahan di pintu kelahiran.

Menjaga janin dari berbagai gangguan maupun untuk menjamin keselamatan janin, maka dilaksanakan ritual oleh masyarakat Bajo. Masyarak Bajo-Laut melaksanakan ritual kehamilan sejak usia kehamilan menginjak usia tiga bulan yaitu pemasangan "sangkine" yang dilaksanakan oleh Panguleatau Biang (Bidan Desa). Sebelum sangkine, ada ritual ada yang dilaksanakan yaitu tiba' pina at au membuang pinang. Dalam ritual ini dibutuhkan bahan yang semuanya disiapkan oleh pihak keluarga seprti:

1. Pinang sebanyak enam buah,

2. Sirih enam buah, kapur satu secukupnya,

3. Tembakau yang sudah dililit dengan kertas menjadi rokok sebanyak enam buah

4. Nasi putih yang lembut sebanyak enam genggam

5. Ikan

6. Daun woka

7. Bambu (bulu cui) dua ujung sepanjang $5 \mathrm{~cm}$

8. Lunga-bongo (buah kelapa utuh yang dibelah tanpa menghilangkan sabut kelapa, kemudian daging kelapanya dikeluarkan. Lunga-bongo menjadi wadah untuk menaruh bahan-bahan yang lain yang akan dihanyutkan). 
Cara pembuatan Tiba-Pina sebagai berikut Lunga bongo diberikan alas dari daun woka, kemudian di dasar diletakkan nasi, kemudian ikan, setelahnya bamboo pada bagian atas bambu diletakan pinang dan rokok, bagian paling luar adalah sirih dan kapur. Lunga bongo ini seperti kapal yang penuh dengan muatan. Setelah tiba-pina siap, maka dihanyutkan di laut oleh pangule dengan membancakan mantra. Setalah tiba-pina, maka dilanjutkan dengan pemasangan sangkine.

Sangkine merupakan kata kerja yang merujuk pada ritual yang dilakasanakan pada usia kehamilan tiga bulan, selain itu, sagkine juga merujuk kepada kata benda yang merupakan artefak kebudayaan yang dipakaikan oleh masyarakat Bajo-Laut kepada ibu hamil. Dalam pembuatan sangkine, dibutuhkan tatali (uang loga kuno bernila 25 cen yang memiliki lubang di tengah), benang berwarna putih dan cincin baik emas maupun perak. cincin dan tatali diikat dengan benang putih yang kemudian diikatkan kepada perempuan hamil oleh pangule yang melaksanakan ritual tiba pina.

Setelah kehamilan mencapai usia tujuh atau delapan bulan mendekati waktu kelahiran, maka dilaksanakan ritual dilekkoang buai, yaitu memandikan ibu hamil. Ritual ini dilaksanakan untuk memudahkan proses kelahiran bayi dan menghindarkan kelahiran bayi dari kaki. Dalam ritual ini dibutuhkan rotan yang sudah dibuat satu lingkaran utuh. Rotan tersebut kemudian dimasukkan dalam wadah yang sudah berisi air kemudian air tersebut dipakai untuk memandikan ibu hamil. Ritual ini dilaksanakan oleh pangule karenya mensyaratkan adanya mantra yang harus diucapkan.

Menjelang kelahiran (usia kehamilan sembilan bulan) maka terdapat ritual yang dilaksanakan yaitu maca kamalekka' atau doa keselamatan. Sebelum kelahiran maka alat maupun bahan yang diperlukan dalam maca kammalekka harus sudah disiapkan guna mengantisipasi kelahiran yang tiba-tiba atau tidak sesuai dengan hari perkiraan lahir. Dalam ritual maca kamalekka dibutuhkan
1. Tido ranta (penutup keranjang yang terbuat dari rotan)

2. Luluppo (belanga kecil yang terbuat dari tanah liat) yang dipakai untuk menanak nasi dan telur ayam kampung

3. Sendok yang terbuat dari kayu

4. Bara api dalam wadah, kemenyam, air putih dan kopi masing-masing satu gelas diletakkan di atas baki.

Setalahnya membaca doa selamat dengan menggunakan bahasa arab, yang dipandu oleh imam. Doa yang dibaca sebagaimana doa selamat pada umumnya. Bara api dipakai untuk membakar kemenyam, kemudian imam memulai dengan membacakan al fatihah, surah al ikhlas, surat al falaq, surat an-nas, al baqarah 1-5, ayat kursi kemudian dilanjutkan dengan membaca doa selamat. Air putih yang sudah di doakan kemudian diberikan kepada perempuan hamil.

\section{Bajo Darat}

Sementara bagi masyarakat BajoDarat pantangan bagi ibu hamil yaitu; Pertama, pada saat hujan dan waktu petang (setalah ashar sampai magrib), maka ibu hamil tidak boleh meksanakan aktivitas di luar rumah. Ketika ibu hamil melaksanakan aktivitas di luar rumah (selain saat hujan dan waktu petang) maka, ibu hamil tersebut harus menutup kepala dengan menggunakan kain. Malam hari, perempuan hamil boleh berkativitas di luar rumah tetapi kata Fadli (Kepala Desa Torosije Jaya) agak rawan diganggu. Pantangan ini ada untuk menjaga janin agar tidak diganggu oleh makhluk ghaib yang dalam pandangan orang Bajo di Torosije banyak berkeliaran pada saat petang maupun gerimis. Adapun memakai kain sebagai tutup kepala merupakan tanda bahwa perempuan tersebut sementara hamil. Hal ini berhubungan dengan respon masyarakat karena bagi masyarakat Bajo, apabila seorang perempuan hamil meminta sesuatu maka harus diberikan karena akan berdampak pada janin apabila apa yang diminta tidak diberikan oleh masyarakat.

Kedua, Ibu hamil juga tidak boleh makan pada wadah yang besar dan duduk maupun berdiri di pintu. Makan di wadah yang 
besar, dalam pandangan orang Bajo, akan mempengaruhi ukuran dari kepala janin saat melahirkan. Makan pada wadah yang besar membuat kepala janin juga menjadi besar sehingga berdampak bayi susah keluar pada saat persanilan normal. Sementara berdiri maupun duduk di pintu akan berdampak pada tertahannya bayi di pintu kelahiran. Ketiga adalah perempuan hamil tidak boleh tidur di Kasur karena akan mengakibatkan ari-ari bayi menjadi lebih tebal.

Ketika kehamilan mencapai usia enam-tujuh bulan dilaksanakan ritual sangkine (membuat pagar diri dari bala untuk perempuan hamil). Selain itu menurut Micing Sairullah (69 tahun) bahwa sangkine juga memiliki fungsi untuk mempercepat proses pertumbuhan janin dalam kandungan.

Selain itu, menjaga gangguan ketika ada terdengar suara burung hantu pada waktu malam hari. Dalam membuat sangkine dibutuhkan: 1) binna' pote yaitu benang berwana putih sesuai dengan lingkar pinggang perempuan hamil 2) dodoi/tatali uang logam kuno 25 sen yang memiliki lubang ditengah. 3) mamane buah kayu bakau (mangrove); 4) kunyit dan bawang merah. Bahan berupa tatali mamane, kunyit dan bawang merah dikaitkan dengan benang berwarna putih kemudian diikatkan kepada ibu hamil dengan mantra. Sebelum pemasangan sangkine, maka ibu hamil terlebih dahulu dimandikan oleh Sandro (dukun) dengan mantra. Setelah pemasangan sangkine maka setiap sepuluh hari (10) pangule melakukan control terhadap kehamilan baik kesehatan janin mapun kesahatan ibu.

\section{Ngana'/ Ana' (Fase Kelahiran)}

\section{Bajo Laut}

Dalam proses kelahiran bagi masyarakat Bajo-Laut, ketika bayi sudah lahir maka yang pertama dilakukan adalah ngitta ponso' (memotong pusat). Pemotongan pusat dilakukan dengan menggunakan uwwe atau kulit bambu yang tajam. Ketika ditanyakan mengapa tidak memakai gunting maka menurut Sangsang Pasandre (75) bahwa memang selama ini memotong pusat selalu menggunakan uwwe, karena memang itu sudah merupakan kebiasaan Orang-Bajo.
Selain $u w w e$ dalam pemotongan tali pusar dibutuhkan tebbe yaitu lempengan belanga dari tanah liat yang sudah pecah serta tatali. Tebbe dan tatali dijadikan sebagai alas untuk melatakan tali pusar yang akan dilaksanakan oleh pangule. Setelah pemotongan tali pusar, kemudian bayi dimandikan kemudian diazankan pada telingan kanan dan iqomat pada telinga kiri. Azan dan iqomat pada umumnya dilaksanakan oleh imam.

Proses selanjutnya adalah temuni yaitu membuang ari-ari bayi. Yang pertama dilakukan adalah membersihkan dodomi ariari ibaratnya manusia, maka dodomi tersebut harus dimandikan terlebih dahulu. Dalam proses tiba kaka ini dibutuhkan bakol atau tikar dari daun pandan yang akan dipakai untuk membungkus dodomi, garam sejumput, beras satu genggam, pinang satu buah, sirih satu buah, rokok satu ujung dan kapus. Setelah dodomo bersih, kemudian diletakkan di dalam bakol dan dibungkus dengan bakol bersama dengan bahan lainnya. Bakol kemudian diikat kemduan diberikan batu sebagai pemberat kemudian ditenggelamkan. Dalam proses tiba kaka dilaksanakan oleh pangule at auorang tua sang bayi yang paham dengan mantra. Pada saat membuang ari-ari maka tidak boleh dilaksanakan pada malam hari, selain itu pangule atau yang melaksanakannya, maka orang tersebut tidak boleh menengok kiri dan kanan.

Setalah tiga hari kelahiran, maka dilakasanakan ritual tiba kaka. Ari-ari merupakan kakak dari sang bayi dan harus diberikan makanan, maka dibuatlah ritual dengan tiba kaka. Dalam ritual ini dibutuhkan nasi tiga genggam, lilin sebanyak tiga ujung, pinang, rokok, sirih masing-masih tiga buah dan kelapa seujung jari sebanyak tiga iris. Semuah bahan tersebut kemudian diletakkan di dalam tempurung kelapa yang memiliki lubang namun terlebih dahulu diberikan alas daun woka. Nasi diletakkan paling dasar, kemudian ditaburi garam, kemudian kelapa rokok, pinang kapur dan siri diletakkan paling atas. Lilin dinyalakan di atas tempurung kemduian ditenggelamkan. Dalam proses tiba kaka dibacakan doa ataupun mantra oleh pangule.

Setelah melahirkan maka sang ibu akan melaksanakan prosesi bantang atau 
pengembalian tenaga kepada sang ibu. Bantang dilaksanakan dengan cara memijat seluruh badan sang ibu. Bahan yang dipakai untuk memijat terbuat dari santan yang dicampur dengan beras yang sudah ditumbuk dan kunyit. Selain itu, juga dibutuhkan kelapa untuk diambil airnya untuk dipakai sebagai minuman dari pangule, ibu maupun orang yang membantu dalam proses bantang.

Bagi masyarakat Bajo-Laut setalah kelahiran bayi, maka sampai tali pusar bayi terlepas, maka sang ayah tidak boleh menyelam, maupun memaku atau menumbuk sesuatu. Bagi sebagian masyarakat harus mengistirahatkan semua aktvitas yang dilakukan oleh sang ayah. Selama tali pusar bayi belum terlepas maka sang ayah kerjannya hanya "makan-tidu" begitu menurut penuturan Sangsang Pasandre, dkk.

\section{Bajo Darat}

Kelahiran atau ana' bagi orang BajoDarat terdapat pantangan yang harus dilaksanakan baik oleh sang ayah maupun ibu. Ayah bayi, tidak boleh melaksanakan aktivitas selama tiga hari atau sampai pusar bari terlepas. Sementara bagi ibu, juga tidak boleh melaksanakan aktivitas yang terlalu berat yang dapat beraktibat terjadinya puga ura/bantahang dan menyebebakan ibu menjadi sakit. Selain itu, ibu tidak boleh mengkonsumsi makanan yang terlalu pedes, maupun daun hijau serta makanan yang bisa menjadikan alergi.

Ketika terjadi kelahiran, bayi sudah keluar dari rahim ibu maka hal pertama yang dilaksanakan adalah pemotongan ari-ari dengan memakai uwwe/sembilu (kulit bambu yang sangat tajam). Tali pusar yang sudah terpotong kemudian diikat dengan benang putih. Setalah tali pusar terpotong dan diikat dengan benang, maka selanjutnya bayi dibersihkan. Setelah dibersihkan, bayi yang bari lahir kemudian dikidam/dikamatang merupakan dao atau ucapan pemasrahan terhadap kehidupan sang bayi. Umar Pasandre (62) mencontohkan ucapan dikamatang dengan menggunakan bahasa melayu Manado: "ini bayi somo kase serahkan kalau mo kase umur panjang, kase umur panjang, tapi kalau somo ambe, atau mati, kase mati saja dari sekarang"

"bayi ini kami pasrahkan, kalau diberikan umur panjang maka berikan umur panjang tapi kalau sudah mau dimabil atau meninggal, maka matikan saja dari sekarang"

Setelah proses dikamatang selesai, maka barulah kemudian sang bayi diazankan pada telinga kanan dan iqomat pada telinga kiri.

Proses selanjutnya tiba kaka yaitu proses pembuangan ari-ari. Ari-ari dalam pandangan orang bajo merupakan saudara kandung (kakak) dari bayi yang baru lahir. Ari-ari terlebih dahulu dibersihkan, kemudian dibungkus dengan kain berwana putih. ari-ari yang sudah dibungkus kemudian dikubur oleh pangule dalam tanah kemudian ditandai dengan kelapa yang sudah memiliki tunas. Tunas kelapa menjadi pangingat bagi bayi yang baru lahir. Tempat penguburan ari-ari disesuaikan dengan permintaan orang tua maupun pihak keluarga. Masyarakat Bajo yang ada di darat sudah tidak ada lagi yang membuang ari-ari ke laut melainkan sudah dikubur di tanah. Pada malam hari, dibuat api di halaman rumah (mugai pundo') kemudian tempat ari-ari diberikan lentera selama tiga hari. Pemberian lentera pada lokasi ari-ari, supaya menjadi penerang pada kehidupan sang bayi nanti.

Pangule memiliki tanggung jawab untuk menjaga dan merawat bayi paling kurang selama tujuh hari, mulai dari memandikan bayi, memakaikan baju sampai menjaga semua dilakukan oleh pangule. Setelah tujuh sampai 10 hari, pewatan bayi diserahkan kepada orang tua. Penyerahan tanggung jawab perawat an anak kepada orang tua ditandai dengan pangule memandikan ibu bayi (diantang) selama tiga hari berturutturut. Dalam proses dibantang, dibuat ramuan untuk mandi dari daun sere, daun dan kulit jeruk (limou susu), dan kunyit. Ramuan itu kemudian dicampur dengan air kemudian dipakai mandi.

Selain itu, rambut dari sang ibu dicuci dengan santan kelapa. Orang tua bayi kemudian harus memberikan upah kepada pangule yang sudah merawat sang ibu ketika 
hamil, sampai melahirkan dan mejaga serta merawat bayi. Tidak ada stadar berapa upah yang harus diberikan kepada pangule, umumnya orang tua bayi sudah dapat memperhitungkan berapa upah yang harus disipakan dan diberikan kepada pangule tersebut.

\section{Kukkor Dan Sunat Perempuan (Fase Bayi)}

\section{Bajo Laut}

Pada masa siklus bayi teradapat ritual yang dilaksanakan oleh orang Bajo laut yaitu kukkor, atau akikah atau gunting rambut. Kukkor dilaksanakan paling lama enam bulan setelah kelahiran. Kukor menjadi pesta, bagi masyarakat Bajo, bagi yang memiliki kemampuan ekonomi tinggi, maka biasanya dibuat pesta yang besar. Syarat yang harus disipakan ketika melaksanakan kukor adalah kambing jantan satu ekor, dengan usia minimal satu tahun. Kukor tidak berbeda jauh secara pelaksanaan syariat dengan aqiqah yaitu pengambilan sebagian rambut pada bayi dan pemebacaan kitab barzanzi.

Sebelum pelaksanaan gunting rambut dan barzanzi maka bayi diberikan kurun tigi yaitu pemberian tanda bagi. Tanda tersebut dibuat dari campuran santan kelapa, kunyit dan beras yang sudah ditumbuk. Campuran santan, kunyit dan beras kemudian dioleskan dengan menggunakan jempol pada bayi di mulai dari bagian ubun-ubun bayi kemudian kepala bagian kanan selanjutnya kepala bagian kiri. Setalah dari kepala, juga dioleskan pada bagian leher, siku tangan kanan, siku tangan kiri kemudian kedua telapak tangangan dengan mendahulukan sebelah kanan. Selanjutnya pada bagian kaki, di lutut dan telapak kaki yang juga mendahulukan sebalah kanan.

Dalam prosesi kukur, bayi digendong oleh ibu kemudian diarak keliling kepada masyarakat yang diundang di mulai dari imam. Imamlah yang akan menggunting rambut bayi dumulai pada bagian atas, kemudian samping kanan, dan selanjutnya samping kiri kepala bayi. Besama dengan bayi tersebut maka ada jajaka yang dibawa terlabih dahulu. Jajaka adalah baki yang berisisi beras putih satu gantang, lilin yang menyala dan soloka/kolongko (kelapa muda yang belum memiliki daging kelapa) yang dilingkari dengan kalung emas dan gunting, pada bagian samping agak ke atas yang dipakai untuk meletakan gunting. Dalam prosesi kukur ini terjadi pembagian kerja antara laki-laki dan perempuan, dimana perempuan bertugas menggendong bayi, sementara laki-laki membawa baki dan payung.

Bagi masyaraka Bajo pada masa bayi, maka bayi juga harus diberikan perlindungan pada saat tidur. Ayunan bayi (toya) di bawahnya diletakan parang yang sudah dipakai, kemudian pada bagian kepala bayi diletakkan songkok/kopiah berawarna hitam. Parang dan songkok yang diletakan dalam ayunan merupakan penangkal dari gangguan sehingga bayi tidak sering menangis. Selain itu, ketika bayi hendak diajak untuk jalanjalan atau dibawah menyebrang laut, maka diberikan sapoy tanda hitam pada kening atau pangkal rambut. Sapoy dibuat dari pelepah daun nipah yang sudah dibakar dan menjadi arang, kemudian dioleskan pada kening sang bayi. Pemberian sapoy juga merupakan penangkal sehingga sang bayi tidak ditegur oleh makhluk ghaib.

Pada siklus bayi ini, perempuan Bajo akan melaksanakan tradisi sunna atau sunat yang dilaksanakan ketika mur bayi antara 5-7 bulan atau ketika bayi sudah bisa duduk. Sunat perempuan dilaksanakan oleh pangule yang mengurus bayi ketika masih dalam rahim. Dalam prosesi ini, diperlukan ayam jantan muda satu ekor yang sudah memiliki jengger. Selain itu juga disiapkan beras satu baki, pinang, sirih dan kapur serta gula merah satu buah, juga jeruk dan telur ayam kampung tiga biji. Semua yang disiapkan diserahkan kepada pangule yang melaksanakan sunat pada perempuan. Sunat perempuan pada masyarakat Bajo, tanpa melukai bagian kelamin dari perempuan. Pisau yang dipakai hanya ditempelkan pada kelamin perempuan sebagai syarat pelaksanaan sunat. Kemudian jengger dari ayam jantan dimabil darahnya untuk kurun tigi. Setelah selesai prosesi sunnat, maka dilanjutkan dengan pelaksanaan doa selamatan.

\section{Bajo Darat}

Kukkor (gunting rambut) juga dilaksanakan oleh masyarakat Bajo Darat secara adat syarat utamanya adalah kambing jantan yang memiliki tanduk sekepal (minimal 
satu tahun) tanpa memiliki cacat. Kambing ini yang nantinya akan disembelih dan dijadikan sebagai hidangan dalam pesta kukor. Dalam prosesi penyembelihan kambing akikah, maka terlebih dahulu kambing harus dimandikan, kemudian tubuhnya diolesi dengan minyak kelapa lalu di sisir dan diberikan bedak. Dalam hal ini sebelum kambing disembelih maka dirias terlebih dahulu. Setalah kambing selesai di rias, maka kambing dibaringkan, kemudian ditutup kain putih dan yang memiliki hajat dengan menggunakan cermin melihat ke wajah kambing yang mau disembelih. Melihat wajah kambing melaui cermin merupakan proses untuk mengantar niat untuk akikah.

Selain kambing, maka pihak keluarga harus menyipakan saloka ngura atau kelapa muda, maya saloka (bunga/mayang kelapa). Juga disiapkan kurun tigi (beras dan kunyit yang ditumbuk dan dioleskan kepada bayi yang akan di kukor. Pada saat pembacaan asraka (barzanji) maka bayi, mayang kelapa, buah kelapa dan payung dibawa keluar dan berkeliling sebanyak tiga kali, dengan urutan orang pertama membawa baki berisi lilin, beras dan kelapa, kemudian orang kedua membawa baki kedua berisi mayang kelapa yang ketiga adalah bayi yang biasanya digendong oleh ibu, dan yang terakhir orang yang memegang payung.

Setelah berkeliling tiga kali dan berhenti di imam, maka imam mengambil beras dang menghaburkannya sebanyak tiga kali. Kemudian diikuti dengan mengambil air kelapa untuk membasahai kepala dari bayi yang kemudian rambutnya dipotong. Rambut yang sudah terpotong kemudian dimasukkan ke dalam kelapa. Jamaah yang hadir, boleh mengusap kepala sang bayi sementara yang menggunting rambut hanya dilaksanakan oleh imam. Setalah rambut sang bayi digunting, maka iring-iringan bayi kembali memutar tiga kali. Setalah selesai memutar, lilin yang dibawa, kemudian dinyalakan dan hanya boleh ditiup oleh ibu kandung dari bayi. Setalah lilin ditiup, maka prosesi kukkor selesai dan dilanjutkan dengan pembacaan doa selamat.

Pada fase bayi, khusus untuk perempuan pada masyarakat Bajo Darat juga dilaksanakan sunna bagi perempuan. Sunat perempuan dilaksanakan ketika bayi mencapai usia 6-7 bulan. Dalam tradisi ini harus disipakan jeruk (limou susui), satu ekor ayam betina yang masih muda, satu butir ayam kampung, kunyit. Dalam tradisi sunat perempuan pada Bajo Darat, ada bagian kelamin wanita yang dipotong/dilukai. Luka tersebut kemudian diberikan penawar dengan mengoleskan putih telur ayam kampung dan kunyit pada bagian alat kelamin perempuan yang luka. Setelah dioleskan maka dilanjutkan dengan melaksanakan doa syukuran. Ayam kampung diberikan kepada pangule yang melaksanakan prosesi sunat.

\section{Sunna dan Baiati (Fase Anak Dan Remaja)}

\section{Bajo Laut}

Pada masa siklus anak maupun remaja masyarakat Bajo Laut akan melaksanakan prosesi sunna (sunantan) pada laki-laki. Berbeda dengan sunnat pada perempuan, yang masih dilaksanakan oleh pangule, sunat pada laki-laki sudah menggunakan tenaga medis. Zaman dulu, sunna masih dilaksanakan oleh dukun, dengan menggunakan sembilu. Sunna dilaksanakan di rumah anak, dengan menggunakan pakaian adat. Usia anak lakilaki yang di sunna berada pada rentang, 10-15 tahun. Sebagaimana sunat pada perempuan, maka pada saat sunat juga disiapkan ayam jantan satu ekor, beras, pinang, sirih dan telur.

Bagi anak perempuan, ketika sudah dewasa, at au mendapatkan haid peertama atau katikaang dalam bahasa Bajo, maka dilaksanakan baiat. Baiat dilaksanakan antara haid pertama dan sebelum haid kedua. Tidak ada tradisi maupun adat yang dilaksanakan pada baiati ini melainkan hanya menggundang masyarakat maupun kerabat dekat kemudian dibuatlah doa syukuran dari keluraga anak gadis tersebut.

\section{Bajo Darat}

Bagi anak remaja laki-laki pada masyarakat Bajo Darat, juga melewati prosesi sunna. Untuk prosesi tersebut dibutuhkan ayam jantan satu ekor, telur ayam kampung satu, pisau bambu, penjempit dari rotan dan batang pisang sepanjang satu meter yang besarnya sudah bisa dipakai untuk dijadikan sebagai tempat duduk, dan kunyit dan juga 
beras yang dipakai sebagai kurun tigi. prosesi awal dari sunant an dimulai dengan pemberian kurun tigi oleh tukang sunat, kemudian dibaiat oleh imam, setalah itu, barulah kemudian prosesi sunat dimulai. Peserta keduduk di batang pisang kemudian dukun sunat membacakan shalawat, kemudian kulit yang menutupi bagian kepala penis dipotong, terlur kemudian dipecahkan dan dioleskan pada bagian kemaluan yang dipotong selanjutnya dibungkus dengan menggunakan kain putih. Setelah prosesi sunat selesai, maka dilanjutkan dengan doa selamatan oleh pihak keluarga.

Dalam tradisi sunat terdapat pantangan yaitu jangan melangnkahi kotoran ayam dan makan makanan yang pedas. Dalam masyarakat Bajo, sunat an secara medis, hanya dilaksanakan apabila ada program sunatan masal dari pemerintah, selebihnya dilaksanakan dengan cara adat, menurut pentuturan informan, perbandingan persentase antara sunat medis dan lokal itu $25 \%$ berbanding $75 \%$.

Bagi anak perempuan remaja yang sudah mendapatkan haid, maka akan melaksanakan prosesi baiat. Prosesi baiat pada Bajo Darat tidak harus dilaksanakan pada haid pertama, namun sangat tergantung dengan kesiapan dan permintaan dari pihak keluarga. Hal ini karena baiat merupakan sebuah pesta besar yang bisa menghabiskan anggaran cukup besar. Dalam prosesi baiat perempuan mengenakan pakaian adat, diberikan kurun tigi, selanjutnya dibaiat oleh imam, selanjutnya doa selamat.

\section{Massuroh, Nyorok Salah dan Nabo Botte (Dewasa-Menikah)}

\section{Bajo Laut}

Memasuki fase dewasa, dan siap menikah, maka masyarakat Bajo mengawali proses ini dengan tradisi pabara. Tradisi pabara, merupakan proses musyawarah awal terkait kapan pelaksanaan lamaran atau massuroh. Pabara dilaksanakan oleh ketua adat, dan ini merupakan suatu yang utama bagi masyarakat Bajo, namun tidak menutup kemungkintan untuk mewakilakan kepada orang lain seperti misalanya imam masjid, atau tokoh masyarakat, maupun orang tua yang menjadi pewakilan dari pihak laki-laki.
Setelah ada kesepakatan terkait waktu pelaksanaan massuroh, maka pihak laki-laki menyiapkan mahar berupa satu pcs/roll kain berwana putih (kurang lebih 30-50 meter), dan uang mahar sebesar Rp. 300.000.

Ketika hari massuroh yang ditentukan sudah tiba maka, mahar berupa kain dan uang dibawa menuju rumah pihak perempuan dengan iringan rebana. Dalam proses massuroh dibicarakan terkait waktu pelaksanaan akad nikah dan pesta termasuk berapa besar biaya yang akan dikeluarkan dalam pelaksanaan pesta pernikahan dan pembagian beban terkait pembiayaan pesta. Waktu pelaksanaan akad nikah bagi masyarakat Bajo tidak lebih dari satu bulan. Biasanya paling lama dua minggu setelah lamaran, akad dan pesta pernikahan langsung digelar.

Ketika hari pelaksaaan akad dan pesta, maka pengantin laki-laki diiringi dengan rebana dan umbul-umbul menuju ke tempat atau lokasi pesta. Rebana dipadukan dengan bacaan sholawat kepada Nabi Muhammad Saw. Setelah samapi di tempat pesta atau rumah perempuan, maka pengantin laki-laki disambut dengan menggunakan gendang oleh pihak perempuan sambil menghaburkan beras ke arah calon mempelai laki-laki sebagai tanda penerimaan dari pihak perempuan.

Setelah proses lamaran selesai, dan menunggu waktu akad atau pesta pernikahan kemudian ada salah satu pihak yang membatalkan lamaran, maka akan dikenakan nyorok salah atau membayar denda kepada adat. Pihak yang membatalkan lamaran menjadi pihak yang harus membayar denda tersebut. Besaran denda adalah setengah dari jumlah kesepakatan harta yang diputuskan saat mussorah. Misalnya setalah laramaran, pihak laki-laki mebatalkan lamaran tersebut, maka pihak laki-laki-lah yang membayar denda pada adat.

Dalam lamaran misalnya disepakati jumlah harta yang harus disiapkan unt uk pesta sebesar Rp. 20.000.000, maka pihak laki-laki harus membayar denda adat sebesar $\mathrm{Rp}$. 10.000.000 kepada adat. Uang tersebut sepenuhnya menjadi hak milik adat, sementara pihak perempuan tidak mendapatkan apapun dari denda tersebut. Dalam hal ini, pihak yang dibatalkan baik 
laki-laki maupun perempuan tidak mendapatkan gati rugi baik secara materil maupun moral karena pembatalan lamaran tersebut.

Penyelesaian konflik karena pembatalan lamaran juga dilaksanakan oleh masyarakat bajo yang dikenal dengan istilah siala danakang. Tradisi ini merupakan keput usan damai ant ar dua pihak keluarga dan diinisiasi dan dimediasi oleh tokoh adat. Dalam tradisi ini, kelurga dari kedua belah pihak dihadirkan termasuk kedua calon mempelai, selain itu juga menghadirkan punggawa (kepala desa). Tradisi ini bertujuan kembali rujuk dan damai walaupun tidak jadi menikah, maka ikatan sebagai satu etnis tetap berjalan. Dalam setiap proses adat dalam pernikahan, maka pelaksana baik tokoh adat, maupun toko agama/masyarakat mendapatkan sedekah dari yang memiliki hajat.

\section{Bajo Darat}

Proses pernikahan pada Bajo Darat dimulai pemberitahun dari pihak laki-laki ke pihak perempuan atau dikenal dengan istilah susuran kadialang. Dalam pemberitahuan ini dilaksanakan oleh orang tua dari pihak lakilaki utuk bertemu dengan orang tua dari pihak perempaun. Pada saat susuran kadialang, dilaksanakan musyawarah untuk menentukan waktu lamaran serta menentukan berapa besar harta yang harus disiapkan oleh pihak lakilaki. Jarak antara susuran kadialang dengan massuroh biasanya berkisar antara satu sampai dua minggu tergantung kesepakatan pada saat musyawarah.

Massuraoh atau prosesi lamaran dilaksanakan dengan menyiapkan mahar berupa satu pcs kain berwarna putih dan uang sebesar Rp. 300.000 untuk gadis, sementara untuk janda satu kali maka setengah dari mahar yang disiapkan untuk gadis. Begitu juga dengan janda dua kali, maka disipakan $1 / 3$ dari mahar gadis. Sebelum pelaksanaan massuroh ada pemberitahuan dari pemangku adat kepada punggawa (kepala pemerintahan/toko agama) yang dalam isitlah masyarakat Bajo di darat disebut pabara. Selain pemberitahuan, pabara juga merupakan undangan kepada punggawa secara adat untuk menghadiri prosesi massuroh. Dalam prosesi lamaran, juga ada negosiasi yang dilaksanakan dengan menggunakan pantun dalam bahasa Bajo.

Negosiasi ini dilaksanakan untuk mendengarkan tawaran maupun pertimbangan dari pihak perempuan. Dalam negosiasi ini akan diambil keputusan apakah lamaran akan diterima atau tidak. Dalam proses negosiasi ini, pihak laki-laki belum membawa mahar, setelah diputuskan lamaran diterima, barulah kemudian mahar diambil dan diserahkan kepada pihak perempuan.

Negosiasi merupakan keputusan final apakah lamaran dari pihak laki-laki diterima atau tidak, namun contemporary negosiasi merupakan praktik adat yang tetap dilaksanakan walaupun sebenarnya keputusan terkait dengan penerimaan atau penolakan lamaran sudah diputuskan pada susurang kadialang. Menurut Fadli Pakaya (33) dia mengatakan bahwa hokum tertinggi bagi Orang Bajo adalah perasaan, jadi kalau mau menolak lamaran pada saat negosiasi itu saat ini sudah tidak pernah terjadi untuk menjaga perasaan keluarga dari pihak laki-laki. Dalam prosesi pengantaran harta, maka diiringi dengan rebana

Ketika pihak laki-laki berasal dari luar daerah, maka pihak pemerintah/adat maupun pihak perempuan sudah menyiapkan tempat yang dekat dengan rumah dari pihak perempuan. Hal ini memudahkan ketika prosesi lamaran dilaksanakan. Dalam prosesi lamaran ketika pihak laki-laki bukan dari Bajo, maka juga dibicarakan terkait dengan adat yang akan dipakai dalam prosesi pernikahan. Selama ini, terjadi kolaborasi adat dalam pelaksanaan pernikahan.

Setelah proses lamaran selesai, maka tinggal menuggu waktu menikah. Menikah bagi masyarakat bajo disebut manikkah. Satu minggu sebelum pelaksanaan pernikahan, perempuan akan dirawat selama satu minggu atau dikenal dengan istilah badaa/barra. Pada hari pesta, maka iringan pengantin laki-laki dibawah dengan rebana setelah sampai di lokasi akad nikah, maka disambut dengan menghamburkan beras dan diberikan kurun tigi bagi pengantin laki-laki, kemudian dilanjutkan dengan prosesi akad nikah. 


\section{Matay/Kapatayang (Kematian)}

Kapatayang merupakan acara yang dilakukan masyarakat paada saat kematian. Ada ritual yang di lakuan yang pertama adalah mandi salah. Mandi salah yang di lakukan oleh pihak keluarga. Yang kedua pembacaan Alquran (dipengajia) sampai hatam yang biasanya dilakukan maksimal tiga hari. Proses pengkafanan dilakukan setelah proses pemandian. kafan yang di gunakan tidak lagi melewati proses apa apa. Pemadian jenazah atau yang sebut mandi maya yang dilakukan sebagaimana umumnya.

Setelah itu disolatkan yang dilakukan kebanyakannya dirumah setelah itu penguburan. Sebelum melakukan penguburan, ada yang dilakukan sebelum penggalian kubur yaitu dalam istilah masyarakat meleku tana (pamitan) menggariskan batas kubur sesuai ukuran jenazah selain garis ada juga patok. Proses ini dilakukan untuk meminta ijin atau malaku tana (meminta tanah) ukuran tanah yang digunakan panjangnya sesuai dengan ukuran panyang mayat dan lebar seukuran empat telapak kaki kurang lebih $75 \mathrm{~cm}$ kedalaman kubur $125 \mathrm{~cm}$ untuk orang dewasa dan 75 untuk anak-anak.

Cara menggaris kubur dengan meletakan pengukur mayat dan menggaris kuburan dengan parang dengan posisi pengukur mayat berada di tengah. Pada presepsi lain setelah penggarisan tanah bagian tengah diambil dan dibuang disamping kuburan kemudian kubur digali sebagaimana biasanya. Bagian dalam kubur ada yang disebut Lilia (lahat) yang digali miring dan dilakukan penguburan sebagaimana umumnya. Setelah penimbunan kubur letak ulunan tanahnya pada keseluruhan kuburan dan pemasangan batu nisan berada pada bagian samping ulunan. Pada hari ke empat puluh baru dapat dilakuakn penggantian nisan. biasanya di ganti dengan kayu, beton, dan paling cenderung di ganti dengan batu.

Setelah prosesi penguburan ada tradisi yang dilakukan yaitu mongarua (do'a arwah) yang dalam istilah masyarakat ini adalah surang tana. Kemudian setelah itu harua yang disebut oleh masyarakat ini adalah ngalabangi yang dilakukan pada hari ke 3, 7 , $14,20,30,40,50,60,70,80,90,100$ yang dilakukan adalah do'a tahlilan, kecuali pada do'a ke 40 ada istilah akikah, ganti batu, dan
Ngareke batu (menghitung batu) batu kerikil di taru di at as kuburan yang sebelumnya sudah dibacakan QS Al-Ikhlas.

Kerikilyang dipakai dalam ngareke batu diambil dari sungai dan dibersihkan, kemdian digelar di atas tikar. Batu kerikil yang di siapkan sebanyak 1111 biji, yang kemudian setiap mengambil satu batu berarti membaca satu kali surat Al Ikhlas sampai seluruh batu selesai kemudian diualang sebanyak tiga kali. Dalam melaksanakan ngareke batu ini bisa berjumlah 5 atau lebih orang. Ngareke batu dilakukan pada malam sebelum 40 hari.

Prosesi lain yang dilaksankan sebelum doa ngalabagi ke 40 adalah pemotongan kambing untuk akikah. Terdapat beberapa hal yang harus dipersiapkan sebelum penyembelihan kambing. Kambing yang nantinya akan disembelih harus jantan yang sudah memiliki panjang tanduk satu kepal (biasaya usia kambing lebih dari satu tahun), kain putih $1 \mathrm{~m}$, sisir, cermin, pupur atau bedak, benang putih, kunyit dan daun kemangi. Sebelum kambing disembelih terlebih dahulu kambing dimandikan, setelah bersih kemudian disisir dan dioleskan kunyit maupun daun kemangih pada seluruh tubuh kambing, setelah itu diberikan bedak. Benang putih kemudian diikatkan melingkar pada rahang kambing sampai ke leher.

Setelahnya kambing kemudian dibaringkan dan diberikan kain putih sebagai tutup. Setalah kambing dibaringkan, maka keluarga melihat wajah kambing melalui cermin yang sudah disipakan. Melihat wajah kambing ini ibarat melihat keluarga mereka yang sudah meninggal, setelah itu kemudian kambing tersebut disembelih. Sebelum ngalabangi atau doa yang dilaksanakan, maka kepala dan bagian dada dari kambing tidak boleh dihancurkan atau dipotong-potong.

Pada masyarakat bajo Darat dalam prosesi kematian, tidak jauh berbeda dengan apa yang terjadi pada masyarakat Bajo Laut. Namun menurut penuturan para informan, dalam prosesi kematian ada beberap tradisi yang sudah hilang seperti ngalengkang maya' atau melangkahi mayat. Prosesi ini dilaksanakan ketika mayat sudah siap dikuburkan, sebelum dibawa keluar dari rumah, maka dilaksanakan prosesi ngalengkang maya'. 
Proses ini hanya dikhususkan bagi keluarga inti dari si mayat. Selai itu ada juga tradisi niba abu atau membuang abu dapur di laut. Ketika dahulu orang Bajo membawa mayat untuk dikuburkan di darat dengan menggunakan perahu, maka dalam perahu yang lain yang mengiringi dilaksanakan pembuangan abu dapur. Pembuangan abu dapur ini untuk membuang semua roh-roh jahat supaya ikut dengan kematian. Pemindahan masyarakat Bajo ke darat memberikan dampak pada kultur masyarakat Bajo.
Masyarakat Bajo dengan tradisi laut yang sudah melekat dalam diri mereka harus melakukan adaptasi ekologi yang baru. Menurut penut uran Muhtar Sompah (56) yang termasuk dalam gelombang pertama pemindahan masyarakat Bajo ke darat, dia mengemukaka bahwa pada saat pertama mereka pindah ke daratan, mereka merasa terganggun dengan suara-suara yang dalam pendengaran mereka asing. Telinga mereka yang terbiasa mendengar riak ombak, kini mulai mendengar suara cacing, dan suara babi dan suara lainnya.

\begin{tabular}{lll}
\hline & & \multicolumn{1}{c}{ KEHAMLAN } \\
\hline Bajo Laut & Bajo Darat \\
\hline Ritual & Bitte' & Bitte' \\
& $\begin{array}{l}\text { Sudah dimulai sejak usia kehamilan } \\
\text { tiga bulan sudah dilaksanakan } \\
\text { pemasagan sangkine dan ritual }\end{array}$ & $\begin{array}{l}\text { Ritual pemasangan sangkine dilaksanakan ketika kehamilan } \\
\text { mencapai usia enam (6) atau tujuh (7) bulan }\end{array}$ \\
\hline Fungsi ritual & $\begin{array}{l}\text { Menjaga janin dari gangguan makhluk } \\
\text { gaib dan memagari diri. }\end{array}$ & Sebagai benteng dari bala. \\
\hline
\end{tabular}

Pada fase kehamilan, terdapat perbedaan mencolok dalam ritual keselamat an bagi janin. Pada masyarakat Bajo Laut, ritual berupa pemasangan sangkine sudah dimulai ketika kehamilan berusia tiga bulan namun pada Bajo Darat pemasangan sangkine dilaksanakan pada usia kehamilan mencapai enam atau tujuh bulan.

\begin{tabular}{|c|c|c|}
\hline \multicolumn{3}{|c|}{ KELAHIRAN } \\
\hline & Bajo Laut & Bajo Darat \\
\hline Bahasa & Ngana' & Ana' \\
\hline Pantangan & $\begin{array}{l}\text { Suami tidak boleh menyelam, bekerja } \\
\text { barat, mamaku sesuatu sampai pusar } \\
\text { bayi terlepas. }\end{array}$ & $\begin{array}{l}\text { Suami tidak boleh beraktivitas selama tiga hari atau sampai } \\
\text { tali pusat terlepas } \\
\text { Istri tidak boleh melakukan aktivitas berat yang menjadikan } \\
\text { istri puga-ura - bantahang yang bisa menjadi penyakit pada } \\
\text { istri. } \\
\text { Istri, tidak boleh makan yang pedes, daun hijau ataupun yang } \\
\text { mengakibatkan alergi. }\end{array}$ \\
\hline Ritual & $\begin{array}{l}\text { Ngita ura (pemotongan tali pusar bayi } \\
\text { Temuni (pembuangan ari-ari ke laut) } \\
\text { Tiba kaka (memberikan makanan } \\
\text { kepada ari-ari) } \\
\text { Bantang (mengembalikan tenaga dari } \\
\text { ibu hamil) }\end{array}$ & $\begin{array}{l}\text { Tiba Kaka menguburkan ari-ari, dan memberikan lentera pada } \\
\text { lokasi tempat penguburan ari-ari. } \\
\text { Dibantang, memandikan ibu }\end{array}$ \\
\hline Fungsi ritual & $\begin{array}{l}\text { Ari-ari merupakan saudara kandung } \\
\text { hidup sang bayi. Memandikan ibu, seb } \\
\text { sampai merawat bayi telah selesai. Sel }\end{array}$ & $\begin{array}{l}\text { ang bayi, pemberian lentera supaya menjadi penerang dalam } \\
\text { anda bahwa proses perawatan dimulai dari kehamilan, kelahiran } \\
\text { a proses perawatan bayi diserahkan kepada orang tua. }\end{array}$ \\
\hline
\end{tabular}

Dalam proses kelahiran, negara dalam hal ini pemerintah daerah memiliki peran dalam perubahan life cicle orang Bajo utamanya yang ada di darat, di mana menurut Fadli Pakaya (33) pemerintah memebuat sebuah aturan yang melarang warga untuk melaksanakan proses persalinan di rumah, melainkan di harus di puskesmas atau rumah sakit. Kamaruddin Mohmmad (62) menambahkan bahwa sebelum tahun 2013 bayi yang lahir semua ditangani oleh Pangule. Dalam proses persalinan tersebut, bidan desa atau pangule bekerja sama dengan bidan pemerintah dalam proses persalinan

Proses kelahiran, utamanya terkait dengan pengetahuan dan praktik antara masayarakat Bajo Laut dan Darat telah terjadi perbedaan. Seperti alasan mengapa tidak menggunakan silet atau gunting ketika memotong tali pusar bayi yang baru lahir, bagi 
masyarakat Bajo-Laut, mereka mengatakan bahwa itu sudah merupakan kebiasaaan. Sementara masyarakat Bajo-Darat menjawab dengan pendekatan medis bahwa pemotongan tali pusar bayi dengan menggunakan logam bisa berdampak pada terjadinya infeksi pada bayi.

\begin{tabular}{lll}
\hline & & FASE BAYI \\
\hline Bajo Laut & Bajo Darat \\
\hline Ritual & Kukkor & Kukkor \\
& Sunna (perempuan) & Sunna (Perempuan) \\
\hline
\end{tabular}

Secara penamaan dan prkatik ritual pada fase bayi tidak terdapat perbedaan antara Bajo Laut maupun Bajo Darat. Namun kelapa yang dipakai dalam ritual kukkor sudah mengalamai perubahan dalam hal values atau nilai. Bagi masyarkat Bajo-Laut lubang kelapa itu berada pada bagian samping agak ke atas dipakai sebagai tempat untuk metakan gunting. Namun pada masyarakt Bajo-Darat, lubang kelapa tidak menjadi masalah apakah dia berada di samping sebagaimana pada Bajo Laut atau kemudian dilubagi pada bagian atas kepala sehingga seperti membuta tutup dari sebuah wadah. Perubahan yang terjadi nampaknya kecila hanya soal lubang pada kepala, namun dalam hal ini, terdapat nilai yang kemudian berubah pada masyarakat Bajo Darat, mereka tidak lagi mempersoalkan hal tersebut.

\begin{tabular}{|c|c|c|}
\hline \multicolumn{3}{|c|}{ FASE REMAJA } \\
\hline & Bajo Laut & Bajo Darat \\
\hline Ritual & Sunna (Laki-laki) & Sunna (laki-laki) \\
\hline & Baiat (perempuan) & Baiat (perempuan) \\
\hline Perbedaan & $\begin{array}{l}\text { Baiat dilaksanakan ketika haid pertama } \\
\text { selesai dan sebelum datangnya masa haid } \\
\text { selanjutnya }\end{array}$ & $\begin{array}{l}\text { Baiat tidak harus dilaksanakan antara haid pertama dan } \\
\text { haid pada bulan selanjutnya. Dapat dilaksanakan kapan } \\
\text { saja, karena perayaan baiat merupakan perayaan pesta } \\
\text { besar. }\end{array}$ \\
\hline
\end{tabular}

Pada ranah nilai dari sebuah ritual, utamanya baiat pada masyakat Bajo Darat sudah mengalami pengaburan terhadap nilai baiat. Baiat dalam pandangan masyarakat bajo harus dilaksanakan sebelum haid berikutnya tidak menjadi keharusan pada masyarakat Bajo yang ada di darat.

\begin{tabular}{|c|c|c|}
\hline \multicolumn{3}{|c|}{ FASE DEWASA/MENIKAH } \\
\hline & Bajo Laut & Bajo Darat \\
\hline \multirow[t]{2}{*}{ Lamaran } & Massoroh & Massuroh \\
\hline & $\begin{array}{l}\text { Diawali dengan pabara pemberitahuan dari } \\
\text { adat. Ketika terjadi pembatalan lamaran } \\
\text { maka dilaksanakan nyorok salah. Untuk } \\
\text { mendamaikan pihak yang batal menikah } \\
\text { maka dilaksanakan siala danakang }\end{array}$ & $\begin{array}{l}\text { Diawali dengan susuran kadialang, kemudian pabara } \\
\text { pemberitahuan sekaligus undangan kepada pihak } \\
\text { pemerintah, pada hari massuroh dilaksanakan negosiasi } \\
\text { selanjutnya prosesi lamaran. } \\
\text { Nyorok salah merupakan penyelesaian ketika lamaran } \\
\text { ditolak. }\end{array}$ \\
\hline \multirow[t]{2}{*}{ Nikah } & Manikkah / nabo botte & Manikkah / Nabo Botte \\
\hline & $\begin{array}{l}\text { Pihak laki-laki diiringi dengan rebana dan } \\
\text { bacaan sholawat dan dibawakan bendera } \\
\text { umbul-umbul. Penyambutan dari pihak } \\
\text { perempuan dengan menghamburkan beras, } \\
\text { dan menabuh gendang sabai tanda } \\
\text { penerimaan }\end{array}$ & $\begin{array}{l}\text { Persiapan pernikahan, perempuan akan dirawat dan tidak } \\
\text { diperkenankan keluar rumah satu minggu sebelum hari } \\
\text { pernikahan, iringan pengantin pria diiringi dengan rebana, } \\
\text { penerimaan pihak perempuan dan pelaksanaan ijab qabul }\end{array}$ \\
\hline
\end{tabular}

Dalam fase dewasa dan persiapan pernikahan mulai dari porsesi lamaran, sangat Nampak kertebukaan orang Bajo Darat dengan perbedaan penkahan dengan beda suku. Hal ini merupakan dampak dari interaksi sosial yang intens antara masyarakat Bajo dengan masyarkat entis lain yang ada di Darat.

\section{PENUTUP}

Pemindahan masyarakat Bajo ke darat memberikan dampak pada culture masyarakat Bajo. Masyarakat Bajo dengan tradisi laut yang sudah melekat dalam diri mereka harus melakukan adaptasi ekologi yang baru. Pemindahan suku bajo kemudian melahirkan segregasi pada masyarakat Bajo sehingga 
melahirkan istilah Bajo Darat dan Bajo Laut. Bagi Bajo Darat, bajo laut merupakan culture core atau pusat kebudayaan orang Bajo sehingga segala bentuk kebudayaan selalu merujuk pada Bajo Laut.

Namun demikian bukan berarti masyarakat Bajo Darat tidak terjadi perubahan, kaitannya dengan ritual dalam siklus hidup telah terjadi perubahan dalam beberapa hal, seperti misalnya kehamilan, kelahiran, dan kematian. Hal yang paling mendasar dalam perubahan dalam siklus hidup dari masyrakat Bajo adalah soal nilai dari sebuah ritual. Ritual pada masyarakat Bajo Darat tetap dilaksanakan namun pada beberapa aspek seakan telah kehilangan esensi dari ritual tersebut. Perubahan yang terjadi selain karena faktor ekology, ternyata kehadiran negara menjadi faktor yang sangat kuat terjadinya perubahan sosial masyarakat Bajo di Darat

\section{DAFTAR PUSTAKA}

Achenbach, Thomas M. 1978. Research in Developmental Psychology Concepts, Strategies, Methods, New York: Free Press

Baruadi, Alif Sahri, 2017. "Short Communication: The Implementation of local wisdom intervention by Bajo People in Eco-Friendly Artisanal Fishery in Torosiaje Gorontalo, Indonesia, Australian Journal of Basic and Applied Science, Vol 11, hal 57 -60

Bennet, J.W. 1996, Human ecology as human behavior; Essay in Environmental and Development Anthropology. London: Transcation Publisher

Creswell, John W. 2013, Penelitian Kualitatif dan Desain Riset, Memilih di antara lima pendekatan, edisi 3, terj. Ahmad Lintang Lazuardi, Yogyakarta: Pustaka Pelajar.

Obie Muhammad, dkk., 2014, "Konflik Etnis di Pesisir Teluk Tomoni Tinjauan Sosio-Ekologi Politik", At-Tahrir, Jurnal Pemikiran Islam, Vol. 14, No. 2 Mei 2014, hal. 319 - 340
Geertz, Clifforf, 1973. The Interpretation of culture: Selected Essay, New York: Basic Book

Hamidun, Marini Susanti, 2016. "Potensi Kawasan Mangrove Untuk pengembangan Ekowisata di Desa Torosiaje Kabupaten Pohuwato, Propinsi Gorontalo", Prosiding Seminar Nasional lahan Basah Tahun 2016, Jilid 3, hal. 1023-1027

Hawley, Amos, 1986. Human ecology; A Theoritical Essay, Chicago: The University of Chicago

Lebar, Frank M (ed), 1975. Ethnic Group of insular South East Asia, Vol 2, Human Relation

Muslim, Abu., Idham., Subair, Muh. 2019. "Iko-Iko Siala Tangang (Tracing Moderatism of Religious Concept From the Oral Traditions of Bajau)" dalam Basri, dkk., (ed) Proceedings of the First International Conference on Religion and Education 2019, October 8-12 2019, Bintaro, Indonesia

Moustakas, C. (1994). Phenomenological Research Methods. London: SAGE Pub

Spradley, James P., 1997, Metode Etnografi, Yogyakarta: PT Tiara Wacana Yogya

Shaugnessy, John J., dkk. 2006, Medodologi Penelitian Psikologi, Terj. Soetjipto dan Soetjipto, Yogyakarta: Pustaka Pelajar

Sembiring, Darma, 1993. Orang Laut di Wilayah Kepulauan Riau Lingga, dalam Masyarakat Terasing, Koentjaraningrat (ed), Jakarta: Gramedia

Spillet, 1993. "Notes on The Sama Bajo People of Sulawesi, Nusa Tenggara Timur and Northern Australia" dalam International Seminar on Bajau Communities, Jakarta: LIPI

Suyuti, Nasruddin, 2011, Orang Bajo di tengah perubahan, Yogyakarta: Penerbit Ombak

Umar, Pola Pemanfaatan dan Pentaan Ruang Kawasan Pemukiman Terapung yang Adaptif terhadap perubahan Iklim" https://researchgate.net/publication/32 6623825 
Usman, Moses, 2013. "Sosio-Kultural Ekologi, Masyrakat Nelayan Suku Bajo Torosiaje Teluk Tomini di Propinsi Gorontalo" Makalah dipresentasikan dalam kongres kebudayaan Indonesia pada tanggal 3 - 8 Oktober 2013di Yogyakarta.

Utina Ramli, 2012, "Kecerdasan Ekologis dalam Kearifan lokal masyarakat Bajo Desa Torosiaje Propinsi Gorontalo", Prosiding Konferensi dan Seminar
Nasional Pusat Studi Lingkungan Hidup Indonesia ke 21"

Zacot, Francois-Robert, 2008, Orang Bajo Suku Pengembara Laut, Jakarta: KPG (Kepustakaan Populer Gramedia)

Zada, Ua, 1996, Nelayan Bajo di Lewalobe di Lembata Kabupaten Flores Timur Nusa Tenggara Timur, Suatu Tinjauan Antropologi Maritim. Skripsi, UGM Yogyakarta 
